IJMS 17 (2), 47-72 (2010)

\title{
IS INFLATION REGRESSIVE OR PROGRESSIVE? LONG RUN \& SHORT RUN EVIDENCE FROM PAKISTAN
}

\author{
MUHAMMAD SHAHBAZ \\ COMSATS Institute of Information Technology, Pakistan \\ ABU N. M. WAHID \\ Tennessee State University, USA \\ RUKHSANA KALIM \\ University of Management and Technology, Pakistan
}

\begin{abstract}
The present paper investigates an answer to a key question "is inflation regressive or progressive?" by utilizing time series data from 1971 up to 2005 with reference to Pakistan. The main focus of the study is on the inflationinequality puzzle but other control variables are also included in the model that affect income distribution. We have utilized the most advanced technique FMOLS (Fully-Modified Ordinary Least Square) for long run and ECM (Error Correction Model) for short run dynamics. Our findings suggest that inflation is progressive in the case of Pakistan but with low magnitude. There is also a prevalence of a U-shaped relationship between inflation and income inequality in non-linear or non-monotonic phenomenon, but it is insignificant. Per capita income deteriorates income distribution, and seems to provide gains to non-poor individuals in the economy. Remittances as share of GDP, and human capital, also appear to increase income inequality in both periods but large size of the government seems to worsen income distribution in the long run. International trade and income inequality are positively correlated that confirms the existence of Leontief paradox in Pakistan not only in short run, but also in long run. Financial development declines income inequality insignificantly. Inverted U-shaped curve (Lafer-Curve) indicates an association of trade and income inequality in non-linear fashion insignificantly. This effort provides some new insights for policy makers and development planners in Pakistan.
\end{abstract}

Keywords: Inflation; inequality; fully modified ordinary least square; Pakistan.

JEL Classification: E31, D31, C32. 


\section{Introduction}

The purpose of present paper is two fold: first, to investigate the linear relationship between inflation and income inequality which tells us "whether inflation is progressive or regressive" and second, to analyze the existence of non-linear (non-monotonic) association between the said variables ${ }^{1}$. Pakistan experienced high-income inequality and poor macroeconomic performance, particularly in the 1980's. In the era of the 1990s, Pakistan faced persistent inflation, hovering between 10 and 13 percent. Continued double-digit inflation, and a large fiscal deficit (approximately 7\% of GDP) were the major reasons for macroeconomic imbalances during the 1990s. The excessive money supply, supply side hurdles, adjustment in administered-prices by government, imported inflation (inflation passes through the adjustment of exchange rate), rise in indirect taxes along with inflationary expectations are considered to be the major reasons for double-digit inflation in Pakistan. Declining trends in inflation during 1999-2002 is the result of tight monetary policy along with better position of supply-side in the economy ${ }^{2}$.

The historical trends of income inequality for the two decades (1980s and 1990s) show that overall income-inequality increases. The Top 20 percent obtains 45.00-50.04 percent of total income at the cost of 80 percent population during 1979-2002 (see Table 1). One may conclude that in 1979, income share of the middle $60 \%$ of the population was $47.6 \%$, while the top $20 \%$ is receiving $45 \%$ of the total income, and $7.4 \%$ is in the lowest $20 \%$, along with an overall $37.3 \%$ overall income inequality. Table 1 provides an evidence that the poor gain from high inflation episodes during the 1990s and low inflation declines their income shares along with improvements in the incomes of the high income class, whereas, overall inequality goes upward during 200102. Recently, inflation in Pakistan leads economic growth positively, due to enhancement in domestic demand. Asset prices of real estates increase as overall prices in the economy rise (Economic Survey of Pakistan, 2007, pp. 128). Perceived wealth effect may be a reason for an increase in aggregate demand in Pakistan. Borrowing against increased equity on real estates in Pakistan is not high. This shows that high level of net wealth is likely to shrink incentives to save. Increase in consumption raises aggregate demand along with upward trends in overall-prices and this improves investment through macroeconomic channel (Keynesian view) in the country. Increased level of investment enhances the employment (for both skilled and unskilled labor) situation that pushes income inequality to decline (Galli \& Hoeven, 2001; Haroon, 2005). The inverse relationship between inflation and income inequality was observed after 1980 (Table 1, Figure 1). 
Table 1

Income Inequality and Inflation

\begin{tabular}{cccccc}
\hline Years & $\begin{array}{c}\text { Household } \\
\text { Gini-coefficient }\end{array}$ & $\begin{array}{c}\text { Household } \\
\text { Lowest 20\% }\end{array}$ & $\begin{array}{c}\text { Income } \\
\text { Middle 60\% }\end{array}$ & $\begin{array}{c}\text { Share of } \\
\text { Highest 20\% }\end{array}$ & $\begin{array}{c}\text { Inflation } \\
(\text { CPI })\end{array}$ \\
\hline 1979 & 37.3 & 7.4 & 47.6 & 45.0 & 11.93 \\
$19849-85$ & 36.9 & 7.3 & 47.7 & 45.0 & 5.61 \\
$1985-86$ & 35.5 & 7.6 & 48.4 & 44.0 & 3.50 \\
$1986-87$ & 34.6 & 7.9 & 48.5 & 43.6 & 4.68 \\
$1987-88$ & 34.8 & 8.0 & 45.3 & 43.7 & 8.83 \\
$1990-91$ & 40.7 & 5.7 & 45.0 & 49.3 & 12.7 \\
$1992-93$ & 41.0 & 6.2 & 45.6 & 48.2 & 9.8 \\
$1993-94$ & 40.0 & 6.5 & 46.3 & 47.2 & 11.3 \\
$1996-97$ & 40.0 & 7.0 & 43.6 & 49.4 & 11.8 \\
$1998-99$ & 41.0 & 6.2 & 44.1 & 49.7 & 5.7 \\
$2001-02$ & 42.0 & 6.30 & N.A & 50.04 & 3.5 \\
\hline
\end{tabular}

Source. Federal Bureau of Statistics and SPDC's Annual Report (2005-06)

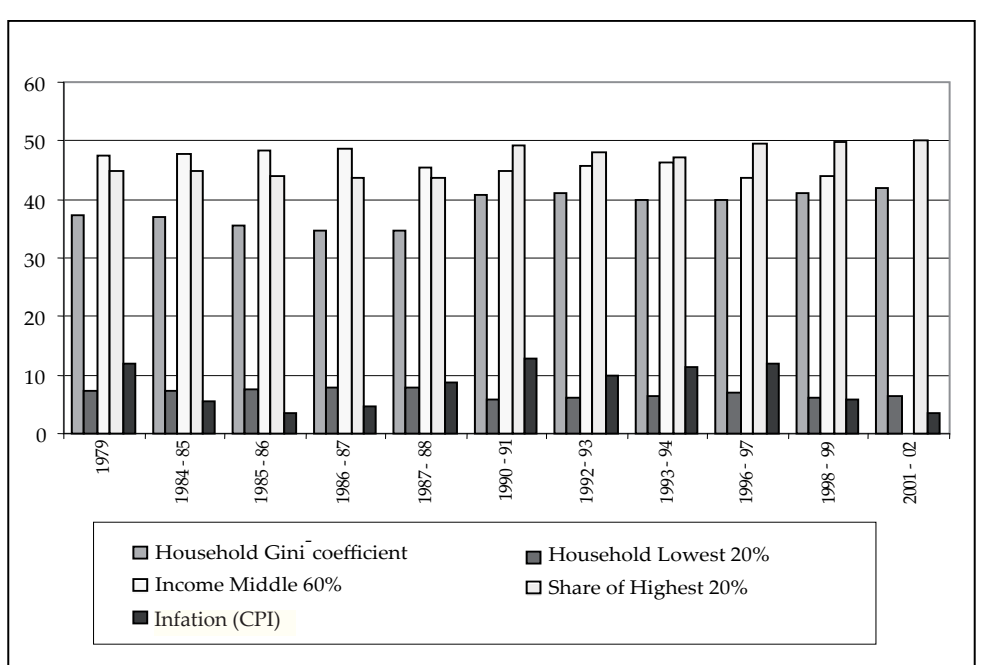

Figure 1. Income inequality and inflation connection.

IJMS 17 (2), 47-72 (2010) 
Low inflation can have impact on income inequality through three main channels in the long run. Firstly, the poor segments of population are more vulnerable to inflationary pressures than the rich class or the non-poor. Due to restrictions in financial markets for non-money monetary assets, the poor class holds greater proportion of their wealth in cash than the rich, because inflation erodes their purchasing power (Ferreira, Prennushi \& Ravallion, 1999) of people across the board. Due to low purchasing power of financial assets, income distribution is improved through controlled monetary policy. Secondly, erosion of real value of non-index public transfers like unemployment benefits and pensions slows down due to lower inflation. This channel improves income distribution because such transfer recipients belong to poor segments of the population. Finally, low inflation slows down the erosion of real value of private debt, because private debt is generally set in nominal terms. If the poor class is net nominal debtor, then this tends to deteriorate the income distribution situation (Galli \& Hoeven, 2001).

Monetary policy does not affect real interest rate in the long run, due to neutrality of money (the so-called Fisher Effect) but real interest rate tends to move upward in the short run. Real interest rate comes back to its initial point when nominal interest rate falls along with expected inflation in the long run. Due to this, the short run negative impact on net borrowers is reversed, which benefits the net borrowers and harms the net lenders in the long run. Therefore, monetary policy does not affect income inequality through real interest rates. Risk premium can be declined through a successful dis-inflation policy when inflation is very high initially. In this phenomenon, real interest rates would be lower in long run; dis-inflation will benefit the net borrowers and hurt the net lenders, improving the income distribution ${ }^{3}$ situation.

This study is a pioneering endeavour to answer the inflation-inequality puzzle (whether inflation regressive or progressive) with reference to Pakistan. The rest of the paper is organized as follows: section II reviews the theoretical and empirical literature; while research methodology and data are described in section III. Section IV focuses on the findings of the study and their interpretation. Finally, section V concludes the paper with some policy recommendations

\section{Review of Literature}

The empirical literature is full with testing the level of development as a major determinant of income distribution in an economy as explained by the so-called Kuznets Law ${ }^{4}$. Some argue that Kuznets

50 IJMS 17 (2), 47-72 (2010) 
hypothesis throws light on some limited variations of income inequality of an economy (Bulir \& Gulde, 1995), and other policy and structural variables such as tax and government expenses, social transfer payments, employment activities, etc. (Milanovic, 1994; Tanzi, 1998; Chu, Davoodi \& Gupta, 2000). Some cross-country studies utilized inflation as an explanatory variable to observe its impact on income distribution measures but do not have interest in scrutinizing inflation-income inequality puzzle with reference to the process of development (Blank \& Blinder, 1986; Bulir \& Gulde, 1995; Romer \& Romer, 1998; Mocan, 1999; Bulir, 2001). Most time series studies for the case of United States found mixed results on inflation-inequality issue. Some claim that inflation increases income inequality, others argue that inflation improves the income distribution while some other find no relationship between inflation and income inequality at all. So, one may conclude that empirical evidence creates inflationinequality a puzzle ${ }^{5}$.

In order to solve the inflation-inequality puzzle, Mocan (1999) concludes that inflation does have progressive effect on income distribution in the case of the United States, but Galli and Hoeven (2001) argue that the impact of inflation on income distribution depends on initial situation of inflation in an economy. Declining inflation reduces income inequality, if inflation is high initially. However, if inflation is at its lower levels initially, then the reducing inflation deteriorates the income distribution. Bulir (2001) confirms that declining inflation from hyper-inflation trends improve income distribution in high inflation economies.

Romer and Romer (1998) suggest that inflation worsens the poor quintile's average income and overall income inequality. Contrary to this, Blank and Blinder (1986) conclude that inflation is inversely associated with the income of the poor segments of the society. Deininger and Squire (1996) also agreed with Romer and Romer's view that well-being of the poor is inversely linked with inflation changes but in a non-linear fashion. Surprisingly, Desai, Olofsgard, and Yousef (2002), report a positive relationship between higher inflation and income inequality, but this correlation still exists contingent upon the political structure prevailing in the country. However, on the other side of the token, conditions for low income inequality would not necessarily tend to lower inflation, if the political structure is handicapped by elites who enjoy access to credits from the financial sector's development (Desai et al., 2005) ${ }^{6}$. Beetsma and Ploeg (1996) argue that democratic society in which the distribution of wealth is unequal, elect political parties that are likely to represent the interests of the poor people. It is in the interest of the clientele of the resulting 
governments to attempt to levy inflation taxes in order to erode the real value of debt service and redistribute from the rich to the poor. Consequently, income inequality and high levels of nominal government debt sow the seeds of inflation. Similarly, Dolmas, Huffman, and Wynne (2000) suggests a positive association between income inequality and inflation and concludes that democratic economies with more independent central banks tend to have better inflation outcomes for any given degree of inequality.

Bulir and Gullde (1995) in their pioneering study for Finland, Israel, and Russia, have come to a conclusion that whether inflation is equivalent to a regressive or progressive tax, mainly depends on the level of development and sophistication of the financial system in the country in question. According to them, in developing economies, with relatively a primitive or less developed financial sector, high inflation deteriorates income distribution. As opposed to it, the poor may gain from high levels of inflation in the economies with highly developed financial sector 7 . In the case of Brazil, Bittencourt (2006) shows that inflation is having regressive and significant impact on income inequality and argues that any possible gain coming from the debtor and creditor channel offsets by the poor performance, combines with incomplete access to financial goods and lower bargaining power regarding earning indexation ${ }^{8}$. Haroon (2006) also found positive correlation between food-inflation and income inequality along with its other important determinants in the case of Pakistan. Albanesi (2007) reports that greater differences in labor productivity create high income inequality that increases the vulnerability of the poor to inflation. This weakens the bargaining power of the poor segments of population. Such situation generates positive correlation between inflation and income inequality.

The non-linear association between inflation and income inequality is represented by an inverted U-shaped curve. Income distribution improves with rise in inflation from low to moderate levels and deteriorates as inflation crosses certain threshold levels. This approach about inflation-inequality relationship is not investigated much in literature with the exception of a few studies. Investigation of non-linear or non-monotonic relationship between inflation and income inequality begins with the pioneering work by Bulir and Gulde (1995). They report that the inflation-inequality relationship is non-monotonic in the case of Finland, Israel, and Russia; but this relationship is conditional with level of economic development and development of the financial markets. Easterly and Fischer (2001) suggest negative correlation between well-being of the poor and inflation change, which implies that higher inflation is inversely 
associated with the well-being of the poor with some non-linear feature. Bulir (2001) also confirms non-monotonic correlation between inflation and income inequality. Galli and Hoeven (2001) investigate non-linear relationships and find a U-shaped curve as theory suggests in inflation-inequality puzzle in the case of the USA. Contrary to this, Crowe (2005) confirms the Bhattacharya and Haslag's (2003) prediction of an inverse-U shaped association between income inequality and inflation through support of empirical evidence.

\section{Modeling, Estimating Methods and Data}

It has been suggested in literature by Bowers and Pierce (1975) that empirical findings are sensitive to a functional form of the model. Similarly, Ehrlich (1977) and Layson (1983) argue on theoretical and empirical grounds that the log-linear form is superior to the linear specification. Based on such theoretical background, the inflation and income inequality relationship is being modelled as follows; ${ }^{9}$

$$
L G I N I=\alpha_{\circ}+\alpha_{1} L I F L+\alpha_{2} C V+\varepsilon_{t}
$$

Where inflation is represented by (IFL), income inequality by Ginicoefficient (GINI), while CV means control variables in the model such as real per capita income (GDPC), government expenditures as share of GDP (GSC), manufacturing value-added as share of GDP (M), secondary school enrollment (SEC) proxy for human capital, investment as share of GDP (INV), remittances as share of GDP (REM), trade openness as share of GDP (TRADE) and financial development by $\mathrm{M} 2$ as share of GDP (M2).

Equation 1 intimates us about linear relation for said variables and investigates that inflation is either regressive or progressive in the case of Pakistan. But investigation of non-monotonic or non-linear relationship between inflation and income inequality is checked through the inclusion of squared term of IFL in Equation 1. Based on the assumption as described in literature, Equation 2 being modelled as following;

$L G I N I=\alpha_{\circ}+\alpha_{11} L I F L+\alpha_{12} L I F L^{2}+\alpha_{13} C V+v_{t}$

The inequality-narrowing hypothesis predicts $\alpha_{11}<0$ and $\alpha_{12}=0$, the inequality-widening hypothesis predicts $\alpha_{11}>0$ and $\alpha_{12}=0$, and inverted U-shaped will be explained through prediction of hypothesis if $\alpha_{11}>0$ and $\alpha_{12}<0$, if $\alpha_{11}<0$ and $\alpha_{12}>0$, U-shaped hypothesis predicts as discussed in the relevant literature ${ }^{10}$.

IJMS 17 (2), 47-72 (2010) 
Pakistan is an open emerging economy and openness of trade can also impact the income inequality to decline or rise. If the trade openness benefits only the elite class of the population, then income inequality increases otherwise improves income distribution. It has been well and comprehensively described in the Loentief Paradox (LaferCurve phenomenon). Openness of an economy may improve income distribution through consumer surplus, that in turn reduces poverty in the country. To observe the effect of the openness on income inequality, both linear and non-linear terms are included in our basic model, i.e. Equation 1. This allows us to construct a new algebraic model for estimation in the form of Equation 3 in the following;

$L G I N I=\gamma_{\circ}+\gamma_{22} L T R D A E+\gamma_{23} L T R A D E^{2}+\gamma_{24} C V+\eta_{t}$

The income distribution-improving hypothesis depicts $\alpha_{22}<0$ and $\alpha_{23}=0$, the distribution of income-worsening hypothesis predicts $\alpha_{22}>0$ and $\alpha_{23}=0$, and inverted U-shaped will be described through assumption of null hypothesis if $\alpha_{22}>0$ and $\alpha_{23}<0$, if $\alpha_{22}<0$ and $\alpha_{23}>0$, U-shaped relationship between trade openness and income inequality as detailed in the relevant literature ${ }^{10}$.

In the experimental econometric investigation, we scrutinized for the effect of inflation on income distribution in the case of a small emerging economy like Pakistan by utilizing the method of FMOLS (Fully Modified Ordinary Least Square). FMOLS has been originally designed by [Philips and Hansen, (1990); Pedroni (1995, 2000); and Philips and Moon (1999)] to provide optimal estimates of cointegration regressions (Bum \& Jeon, 2005). This technique employs Kernal estimators of the Nuisance parameters that affect the asymptotic distribution of the OLS estimator. In order to achieve asymptotic efficiency, this technique modifies least squares to account for serial correlation effects and tests for the endogeneity in the regressors that result from the existence of a co-integrating relationship ${ }^{11}$. Although this non-parametric approach is an elegant way to deal with nuisance parameters, it may be problematic especially with fairly very small samples.

To apply the FMOLS for estimating long-run parameters, the condition that there exists a co-integrating relationship between a set of I(1) variables is satisfied. Therefore, primarily we have to confirm the presence of the unit root and test the co-integrating relationship. Standard tests of the presence of the unit root based on the work of Augmented Dicky Fuller and Philip-Perron (P-P) have been used to investigate the degree of integration among the variables.

54 IJMS $17(2), 47-72(2010)$ 
Engle and Granger (1987) discussed that, if a set of economic series is not stationary, there may exist some linear combination of the variables that are stationary. Now, when all the variables are nonstationary at their levels but stationary in their first differences, this allows us to proceed further for the implementation of Johansen co-integration technique. Econometrically speaking, two variables will be co-integrated if they have a long-term relationship between them. Thus, co-integration of two series suggests that there is long integration tests and of course, the system approach developed by Johansen (1991, 1995) and Johansen and Juselius (1990) can also be applied to a set of variables containing possibly a mixture of $\mathrm{I}(0)$ and I(1) (Pesaran \& Pesaran, 1997; Pesaran, Shin \& Smith, (2001). The general form of the vector error correction model is as follows;

$$
Z_{t}=\sum_{i=1}^{p-1} \psi Z_{t-1}+\alpha_{\circ}+\eta_{t}
$$

This can also be written in standard form as:

$$
\Delta Z_{t}=\sum_{i=1}^{p-1} \Pi_{i} \Delta Z_{t-k}-\partial Z_{t-k}+\alpha_{1}+\varepsilon_{t}
$$

where;

$$
\begin{aligned}
& \prod_{i}=-I+\partial_{1}+\partial_{2}+\ldots \ldots+\partial_{t} \\
& i=1,2,3, \ldots k-1 \text { and } \partial=I-\partial_{1}-\partial_{2}-\ldots \partial_{k}
\end{aligned}
$$

Where $p$ represents total number of variables considered in the model. The matrix $\prod$ captures the long-run relationship between the $p$-variables. Now for the Johansson test; we employed the Trace test, which is based on the evaluation of $H_{\circ}(r-1)$ against the null hypothesis of $H_{\circ}(r)$, where $r$ indicates number of cointegrating vectors. The co-integration test provides an analytical statistical framework for investigating the long-run relationship between economic variables in the model. Johansen and Juselius (1990) provided critical values for the two statistics. The statistical distribution depends on the number of non-stationary components and model telling of constants and trend terms. To determine the nonstationary components, it is necessary to choose the lag length for VAR portion of the model. To overcome this problem, this work determines the optimal lag length using Akaike Information Criterion (AIC) and Schwartz Bayesian Criterion (SBC) ${ }^{12}$. The lowest values of AIC and 
SBC to select the lags give the most desirable results. To investigate the short run impacts of inflation plus control variables on income inequality, ECM version of the model is followed, as portrayed below;

$$
\Delta L G I N I=\alpha_{1}+\alpha_{2} \Delta L I F L+\alpha_{3} \Delta C V+\eta e c m_{t-1}+\mu_{t}
$$

The stability test was also conducted by employing the cumulative sum of recursive residuals (CUSUM) and the cumulative sum of squares of recursive residuals (CUSUMsq). Data of government spending as share of GDP, manufacturing value added to GDP, foreign remittances as share of GDP and $\mathrm{M}^{13}$ (liquid liabilities) as share of GDP were obtained from World Development Indicators (WDI, 2005). Economic Survey of Pakistan (2005) has been consulted to obtain data on inflation, trade as share of GDP (exports + imports as share of GDP), secondary school enrolments and investment as share of GDP. The data of income inequality i.e. gini-coefficient, have been collected by Haroon (2005). Theoretical intuitions and the expected signs of the parameters are explained in the Table 2.

\section{Table 2}

\begin{tabular}{llc}
\hline Variables & \multicolumn{1}{c}{ Theory Intuition } & $\begin{array}{c}\text { Expected } \\
\text { Sign }\end{array}$ \\
\hline Inflation & $\begin{array}{l}\text { Poor segments of population are more vulnerable } \\
\text { to inflation than non-poor because the latter class }\end{array}$ & $+/-$ \\
& $\begin{array}{l}\text { has better access to financial instruments that } \\
\text { allow them to hedge their exposure to inflation } \\
\text { and expecting positive effect of inflation on income } \\
\text { inequality and vice versa as explained in literature. }\end{array}$ & \\
&
\end{tabular}

Real per Capita Economic growth improving income distribution Income through pro-poor policies but effect can be opposite if gains from growth goes to upper segments of $-1+$ population.

\begin{tabular}{ll}
\hline Secondary & Human capital formation may increase income \\
Enrollment & inequality. It is assumed that elite class of society \\
& spends more on education, health, food, and other \\
facilities as compared to the poor segment of the \\
population. This enables the people from elite class \\
to be more productive and in resulting income \\
inequality increase. If the education is easy to get \\
for poor people then it will improve the productive \\
capacity of the whole nation that accelerates \\
economic growth rate. Economic growth improves \\
income distribution through trickle down effect.
\end{tabular}

(continued) 


\begin{tabular}{|c|c|c|}
\hline Variables & Theory Intuition & $\begin{array}{c}\text { Expected } \\
\text { Sign }\end{array}$ \\
\hline $\begin{array}{l}\text { Government } \\
\text { Spending }\end{array}$ & $\begin{array}{l}\text { Government general consumption expenditures } \\
\text { conjecturing negative effect on income inequality, } \\
\text { but there can be opposite effect of government } \\
\text { consumption on inequality, if the rich households } \\
\text { that use their political power to exploit the poor and } \\
\text { political structure is handicapped by the elites who } \\
\text { enjoy access to credits from the financial sector }{ }^{14} \text {. }\end{array}$ & $-1+$ \\
\hline $\begin{array}{l}\text { Trade- } \\
\text { Openness }\end{array}$ & $\begin{array}{l}\text { Trade-openness improves the income distribution, } \\
\text { if policies are favourable equally for both the } \\
\text { skilled as well as for unskilled labor and vice versa. }\end{array}$ & $-1+$ \\
\hline Remittances & $\begin{array}{l}\text { Remittances representing impact of international } \\
\text { migration also affects income inequality either } \\
\text { positively or negatively. As Stark, Taylor, and } \\
\text { Yitzhaki (1986) distinguish that the distributional } \\
\text { impacts of migration are not the same for all types } \\
\text { of migration and; concluded that international } \\
\text { remittances contribute in raising income } \\
\text { inequality. An increase in international remittances } \\
\text { stimulates economic growth in the country and in } \\
\text { turn, economic growth redistributes the income } \\
\text { distribution through trickle down effect. }\end{array}$ & $+/-$ \\
\hline Investment & $\begin{array}{l}\text { Investment activities generate employment } \\
\text { opportunities both for the skilled and unskilled } \\
\text { labor. This boosts incomes of lower segments of the } \\
\text { population and improves income distribution in an } \\
\text { economy. }\end{array}$ & - \\
\hline Manufacturing & $\begin{array}{l}\text { Manufacturing sector's value added as share } \\
\text { of GDP shows impact of the sectoral structure } \\
\text { of an economy and having income distribution } \\
\text { equalizing influence. }\end{array}$ & - \\
\hline $\begin{array}{l}\text { Financial } \\
\text { Development }\end{array}$ & $\begin{array}{l}\text { Financial intermediation may decline income } \\
\text { inequality directly and indirectly through growth } \\
\text { process. }\end{array}$ & - \\
\hline
\end{tabular}

\section{Empirical Results and Interpretation}

Since, the present study appears to be an initial attempt to identify the links between inflation and income inequality in the case of a small developing economy like Pakistan, therefore, we empirically estimate whether a statistically significant relationship exists between measure of inflation and income distribution in the long run as well as in the short run. 
Table 3

Unit-Root Procedure

\begin{tabular}{|c|c|c|c|c|c|c|}
\hline \multirow[b]{2}{*}{ Variables } & \multicolumn{3}{|c|}{ ADF at Level } & \multicolumn{3}{|c|}{ Philip-Perron at Level } \\
\hline & $\begin{array}{c}\text { Intercept } \\
\text { and } \\
\text { trend }\end{array}$ & Prob-value & Lags & $\begin{array}{l}\text { Intercept } \\
\text { and trend }\end{array}$ & Prob-value & Lags \\
\hline LGINI & -0.969 & 0.9348 & 1 & -0.9919 & 0.9320 & 3 \\
\hline LIFL & -2.401 & 0.3715 & 3 & -3.1427 & 0.1130 & 1 \\
\hline LTRADE & -2.797 & 0.2081 & 1 & 0.8550 & .8903 & 3 \\
\hline LGDPC & -2.692 & 0.2459 & 2 & 0.1924 & 0.9681 & 2 \\
\hline LSEC & -1.671 & 0.4357 & 1 & -1.5546 & 0.4943 & 3 \\
\hline LGSC & -0.271 & 0.9189 & 1 & -0.6548 & 0.8448 & 3 \\
\hline LM & -1.827 & 0.3610 & 2 & -2.4292 & 0.1416 & 3 \\
\hline LINV & -2.288 & 0.1826 & 4 & -2.5717 & 0.1086 & 4 \\
\hline LREM & -2.030 & 0.2227 & 5 & -1.9995 & 0.3022 & 3 \\
\hline LM2 & -2.552 & 0.1134 & 3 & -2.7404 & 0.2279 & 3 \\
\hline \multicolumn{7}{|c|}{ At $1^{\text {st }}$ Difference } \\
\hline LGINI & -5.590 & 0.0004 & 1 & -5.491 & 0.0004 & 1 \\
\hline LIFL & -5.035 & 0.0015 & 0 & -4.965 & 0.0017 & 3 \\
\hline LTRADE & -4.683 & 0.0040 & 3 & -6.807 & 0.0000 & 1 \\
\hline LGDPC & -5.188 & 0.0010 & 0 & -5.171 & 0.0010 & 3 \\
\hline LSEC & -4.419 & 0.0068 & 0 & -4.415 & 0.0069 & 1 \\
\hline LGSC & -4.607 & 0.0043 & 0 & -4.638 & 0.0040 & 3 \\
\hline LM & -4.595 & 0.0048 & 2 & -5.920 & 0.0001 & 2 \\
\hline LINV & -5.224 & 0.0009 & 0 & -5.216 & 0.0009 & 3 \\
\hline LREM & -3.265 & 0.0903 & 1 & -7.620 & 0.0000 & 5 \\
\hline LM2 & -5.789 & 0.0002 & 1 & -4.210 & 0.0113 & 3 \\
\hline
\end{tabular}

* MacKinnon (1996) one-sided p-values.

The first step in this analysis consists of establishing the order of integration of each variable. For this purpose, to get reliable results

58 IJMS $17(2), 47-72(2010)$ 
for Equation 1, the implicit assumption is that variables in Equation 1 are $I(1)$ and co-integrated. In doing so, we employ the test for the existence of a unit root in the level and first difference of each of the variables in our sample using the Augmented Dickey Fuller (ADF) and Philip-Perron tests. ADF and P-P test statistics check the stationarity of series as represented in Table 3 . Both tests prove that all the variables in Equation 1 are non-stationary at level i.e. I(0) and stationary as the their first difference form of I (1). One may conclude that all these concerned variables are having $I(1)$ integrating order. The similarity of integrating order of variables lends support to apply the Johansen cointegration technique for long run relationship among the variables.

Table 4 summarizes the results of cointegration analysis between income inequality and inflation plus other determinants ${ }^{15}$. The results from the Johansen co-integration analysis both the maximum eigen value and the trace-test value examined the null hypothesis of no cointegration against the alternative hypothesis of cointegration have given. Starting with the null hypothesis of no cointegration $(\mathrm{R}=0)$ among the variables, the trace-test statistics is 764.254, which is above 5 percent critical value 273.189 respectively (prob-values are also shown in the Table 4). Hence it rejects the null hypothesis $R \leq 0$ in the favor of the alternative hypothesis $\mathrm{R}=1$. It is witnessed in Table 4 that the null hypothesis of $\mathrm{R} \leq 1$ can be rejected at 1 percent level of significance hence its alternative of $R=2$ is accepted. Consequently, one may conclude that there are eight cointegrating relationships (vectors) among gini-inequality, inflation, GDP per capita, trade as share of GDP, secondary school enrollment, government spending, manufacturing as share of GDP, investment as share of GDP, remittance as share of GDP, and financial development.

Turning to the maximum eigen value test, the null hypothesis of no cointegration $(R=0)$ is rejected at 1 percent level of significance in the favor of general alternative. This shows that there is one cointegrating vector, $R=1$. The test also rejects the null hypothesis of $R=1 \mathrm{in}$ favor of the alternative $R=2$. This confirms the conclusion that overall, there are six co-integrating relationships amongst the ten I(1) variables. Our decision is based on trace-test statistics because it is more powerful and reliable than maximum eigen values ${ }^{16}$. One may document that there exists a stable long-run relationship among Gini-inequality, inflation, GDP per capita, trade as share of GDP, secondary school enrollment, government spending, manufacturing as share of GDP, investment as share of GDP, remittance as share of GDP and financial development from 1971 up to 2005 time period. 


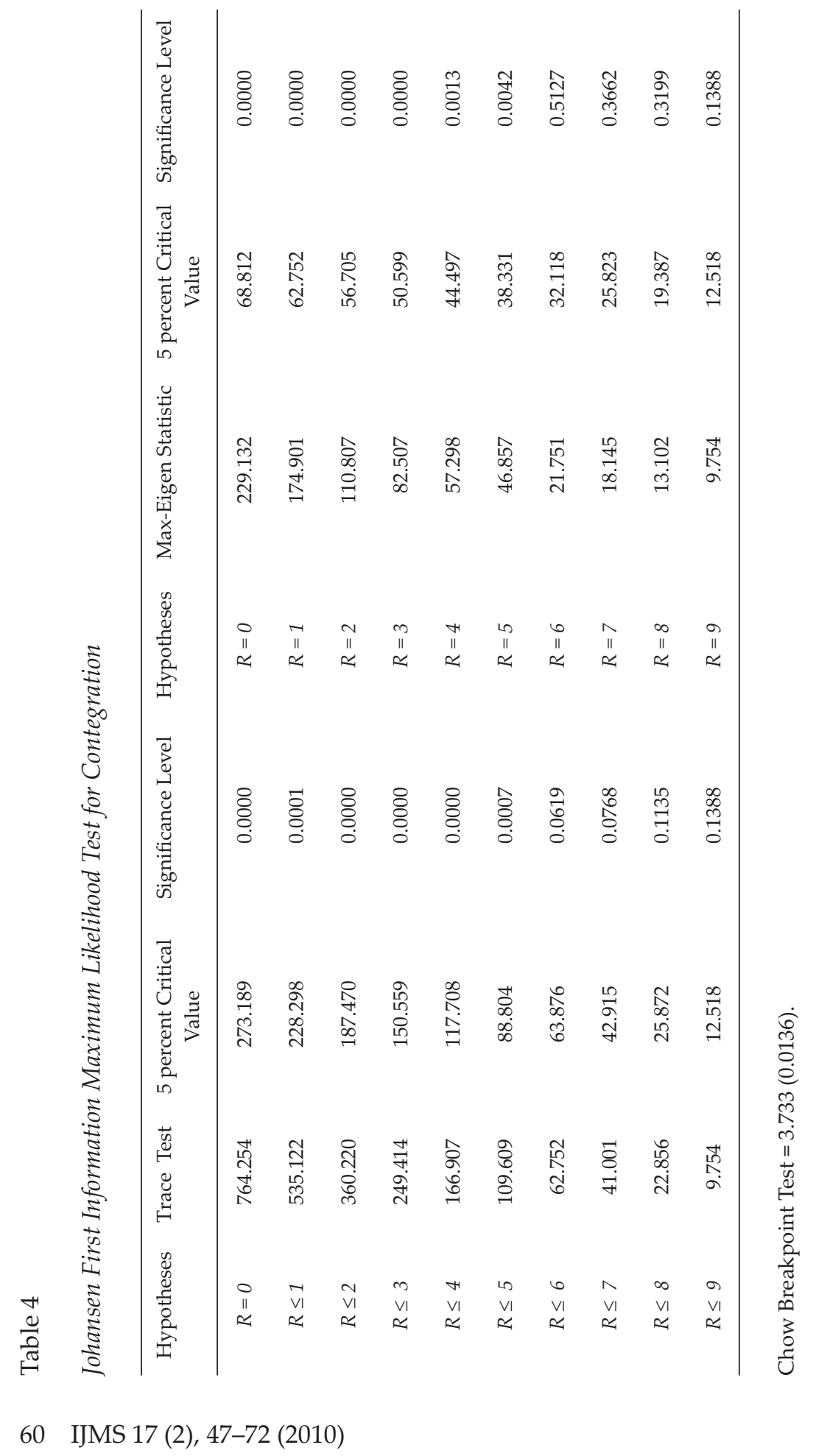


Next step is to apply FMOLS method for the estimation of long run parameters, after the satisfaction of existence of cointegration relation between a set of $I(1)$ variables in our data set. Table 5 shows the estimated results from FMOLS analysis of Equation 1, Equation 2, and Equation 3. The main focus in this study is on the relationship between inflation and income inequality puzzle. The linear model indicating that inflation is inversely associated with income inequality that means inflation is progressive in the case of Pakistan but the magnitude of inequality declines due to an increase in inflation is very low ${ }^{17}$.

Table 5

OLS Regression Results

\begin{tabular}{|c|c|c|c|}
\hline \multicolumn{4}{|c|}{ Dependent Variable $=$ LGINI $^{18}$} \\
\hline Variables & Coefficient & Coefficient & Coefficient \\
\hline Constant & $\begin{array}{l}0.8961 \\
\mathbf{( 0 . 0 0 0 )}\end{array}$ & $\begin{array}{c}0.8956 \\
\mathbf{( 0 . 0 0 0 )}\end{array}$ & $\begin{array}{c}0.6615 \\
\mathbf{( 0 . 2 5 2 7 )}\end{array}$ \\
\hline LIFL & $\begin{array}{r}-0.0062 \\
\mathbf{( 0 . 0 4 7 3 )}\end{array}$ & $\begin{array}{c}-0.0086 \\
\mathbf{( 0 . 6 9 5 1 )}\end{array}$ & $\begin{array}{c}-0.0061 \\
\mathbf{( 0 . 0 9 0 3 )}\end{array}$ \\
\hline LIFL $^{2}$ & - & $\begin{array}{c}0.0006 \\
\mathbf{( 0 . 9 1 1 1 )}\end{array}$ & - \\
\hline LGDPC & $\begin{array}{c}0.1457 \\
(0.0000)\end{array}$ & $\begin{array}{c}0.1458 \\
(0.000)\end{array}$ & $\begin{array}{c}0.1376 \\
(\mathbf{0 . 0 0 0 )}\end{array}$ \\
\hline LGSC & $\begin{array}{c}0.0263 \\
(0.0069)\end{array}$ & $\begin{array}{c}0.0268 \\
(0.0142)\end{array}$ & $\begin{array}{c}0.0218 \\
(0.0216)\end{array}$ \\
\hline LREM & $\begin{array}{r}0.0155 \\
\mathbf{( 0 . 0 0 0 )}\end{array}$ & $\begin{array}{c}0.0155 \\
\mathbf{( 0 . 0 0 0 )}\end{array}$ & $\begin{array}{c}0.0159 \\
(\mathbf{0 . 0 0 0 )}\end{array}$ \\
\hline LSEC & $\begin{array}{c}0.0989 \\
(\mathbf{0 . 0 0 0 )}\end{array}$ & $\begin{array}{c}0.0989 \\
(\mathbf{0 . 0 0 0 )}\end{array}$ & $\begin{array}{c}0.1011 \\
(\mathbf{0 . 0 0 0 )}\end{array}$ \\
\hline LTRADE & $\begin{array}{c}0.0980 \\
(\mathbf{0 . 0 0 0 )}\end{array}$ & $\begin{array}{c}0.0975 \\
(0.000)\end{array}$ & $\begin{array}{c}0.1733 \\
(0.5665)\end{array}$ \\
\hline LTRADE $^{2}$ & - & - & $\begin{array}{c}-0.0115 \\
\mathbf{( 0 . 7 9 9 5 )}\end{array}$ \\
\hline LINV & $\begin{array}{c}-0.0495 \\
\mathbf{( 0 . 0 0 1 1 )}\end{array}$ & $\begin{array}{c}-0.0478 \\
\mathbf{( 0 . 0 2 9 1 )}\end{array}$ & $\begin{array}{c}-0.0436 \\
\mathbf{( 0 . 0 0 6 3 )}\end{array}$ \\
\hline LM & $\begin{array}{c}-0.0778 \\
\mathbf{( 0 . 0 5 2 6 )}\end{array}$ & $\begin{array}{c}-0.0795 \\
\mathbf{( 0 . 0 6 8 6 )}\end{array}$ & $\begin{array}{c}-0.0521 \\
\mathbf{( 0 . 1 8 7 3 )}\end{array}$ \\
\hline LM2 & $\begin{array}{c}-0.0218 \\
\mathbf{( 0 . 1 1 8 1 )} \\
\end{array}$ & $\begin{array}{c}-0.0213 \\
\mathbf{( 0 . 1 4 8 4 )}\end{array}$ & - \\
\hline $\begin{array}{l}\text { R-squared } \\
\text { Adj-R-squ } \\
\text { AIC }=-7.2 \\
\text { Durbin-W } \\
\text { F-Stat }=13\end{array}$ & $\begin{array}{l}869 \\
.997101 \\
1.838 \\
.000)\end{array}$ & $\begin{array}{l}\text { R-squared }=0.997870 \\
\text { Adj-R-squared }= \\
0.996982 \\
\text { AIC }=-7.232162 \\
\text { Durbin-Watson }=1.825 \\
\text { F-Stat }=1124.171(0.000)\end{array}$ & $\begin{array}{l}\text { R-squared }=0.997651 \\
\text { Adj-R-squared }= \\
0.996806 \\
\text { AIC }=-7.191771 \\
\text { Durbin-Watson }=1.582 \\
\text { F-Stat }=1179.954(0.000)\end{array}$ \\
\hline
\end{tabular}

Note. prob-values are given in parentheses.

IJMS 17 (2), 47-72 (2010) 
Second determinant of income distribution is GDP per capita that captures the effect of economic growth in the economy. This shows that 1 percent increase in economic growth pushes income inequality upward by 0.1457 percent in Pakistan. This also indicates that the poor are not benefited much from economic growth and the rich captures the major share of national income.

Higher government expenditures are associated with higher income inequality. This asserts that income distribution may be improved; if size of the government is small because reducing government spending is an example of policy that is "super pro-poor". This not only raises the overall incomes, but also appears to have a positive effect on the distribution of income in the economy and does increase the incomes of the poor-segments of the society (Dollar \& Kraay, 2000). High government expenditures also show that the poor class is also exploited through political connections of the non-poor individuals, and the political structure is handicapped by the elites who enjoy access to credits from the financial sector and there prevails a tendency to worsen income inequality.

An increase in remittances and enhancement in human capital are also major contributors in deteriorating income distribution in Pakistan. Poor segments have no extra money to send their children abroad, therefore non-poor obtains the gains from that side, also invest more in the education of their children than the poor. In an open economy skilled labor is demanded more than the non-skilled ones and same phenomenon is true for cases abroad. Therefore, they move to higher segment of incomes, means income inequality increases. Trade represents phenomenon of openness, whereas income inequality increases as trade expands. One may conclude that 1 percent increase in trade deteriorates income distribution by 0.0980 percent. This shows that the elite and the non-poor obtain gains from international trade but less goes to the poor indicating the presence of Leontief Paradox in Pakistan $^{19}$.

Creating a congenial investment environment generates employment opportunities for unskilled as well as skilled labor. This raises the incomes of the poor segments of population. Income distribution improves by 0.0495 percent through 1 percent increase in investment opportunity in the economy. Negative and significant coefficient of manufacturing shows that greater share of manufacturing contribute to GDP that improves income distribution. Finally, coefficient of financial development does not improve income distribution significantly. 
The non-linear or non-monotonic relationship between inflation and income inequality puzzle is observed in the case of Pakistan through the specification of Equation 2. We included the squared term of inflation in the linear model and find that insignificant U-shaped correlation between inflation and income inequality prevails. This indicates that income distribution improves initially as inflation rises, at certain levels. All other variables are with their expected signs in the model. Additionally, we include the squared term of trade in Equation 1 and get Equation 3 to investigate the phenomenon of Lafer curve in Pakistan ${ }^{20}$. The estimation confirms the existence of the inverted-U shaped curve (Lafer-Curve) in Pakistan but is was insignificant. The main reason for this non-linear relationship is that Pakistan is not highly open-economy, and therefore, the privileged class reaps fruits of trade-openness as Leontief-Paradox suggests. Diagnostic tests are posted in Table 6.

The table shows that there is no serial correlation and no auto-regressive conditional heteroscedisticity in the model while the error term is also normally distributed as indicated by Jarque-Bera value at 36 percent level of significance approximately. Estimates also confirm that there is no heteroscedisticity in the regressed model. ADF test also proves the normality of residual term. Finally, residuals tests "cumulative sum (CUSUM) and the cumulative sum of squares (CUSUMsq)" are employed for stability of long-run partial impacts of independent variables on dependent actor.

Table 6

Diagnostic Tests

\begin{tabular}{lcccc}
\hline $\begin{array}{l}\text { LM Test for } \\
\text { Serial-Correlation }\end{array}$ & F-statistic & Probability & $\begin{array}{c}\text { Obs* } \\
\text { R-squared }\end{array}$ & Probability \\
\hline $1^{\text {st }}$ Degree & 0.1755 & 0.6789 & 0.2541 & 0.6141 \\
$2^{\text {nd }}$ Degree & 0.1549 & 0.8573 & 0.4651 & 0.7924 \\
$3^{\text {rd }}$ Degree & 1.0980 & 0.3709 & 4.5581 & 0.2071 \\
\multicolumn{1}{c}{ Auto-Regressive Conditional Heteroscedisticity (ARCH) Test } \\
$1^{\text {st }}$ Degree & 0.5832 & 0.4506 & 0.6086 & 0.4353 \\
$2^{\text {nd }}$ Degree & 0.6389 & 0.5348 & 1.3482 & 0.5096 \\
$3^{\text {rd }}$ Degree & 0.4325 & 0.7313 & 1.4173 & 0.7014 \\
J-B for Normality & 2.3728 & 0.3051 & & \\
White-Heteroscedisticity & 0.4574 & 0.4574 & 11.8914 & 0.8527 \\
\hline \multicolumn{5}{r}{} \\
\end{tabular}

IJMS 17 (2), 47-72 (2010) 


\begin{tabular}{|c|c|c|c|c|}
\hline $\begin{array}{l}\text { LM Test for } \\
\text { Serial-Correlation }\end{array}$ & F-statistic & Probability & $\begin{array}{l}\text { Obs*R- } \\
\text { squared }\end{array}$ & Probability \\
\hline \multirow{2}{*}{ ADF test Calculated Value } & None & Intercept & \multirow{2}{*}{\multicolumn{2}{|c|}{$\begin{array}{l}\text { Intercept and Trend } \\
\qquad-5.167(0)\end{array}$}} \\
\hline & $-5.317(0)$ & $-5.237(0)$ & & \\
\hline Probability & 0.0000 & 0.0001 & \multicolumn{2}{|c|}{$0.0010^{*}$} \\
\hline
\end{tabular}

Short run Diagnostic Tests

Serial Correlation LM Test $=0.0444(0.8353)$

ARCH Test $=1.780(0.1657)$

White Heteroscedisticity $=0.576(0.8590)$

Jarque-Bera $=1.521(0.4672)$

Ramsey RESET Test $=0.608(0.4450)$

Note. *MacKinnon (1996) one-sided p-values and lags are selected in ADF test on the basis of AIC criteria which are in parentheses. Prob-values of short run diagnostic are pasted in parentheses.

Following Bahmani-Oskooee and Nasir (2004), the null hypothesis (i.e. that the regression equation is correctly specified) cannot be rejected if the plot of these statistics remains within the critical bounds of the 5 percent significance level. As it is witnessed from Figures 2 and 3, the plots of both the CUSUM and the CUSUMsq are within the boundaries. This leads to conclude that statistics confirm the stability of coefficients of regressors that affect income distribution in Pakistan positively or negatively. The model appears to be stable and correctly specified with an indication that neither the CUSUM nor the CUSUMsq test statistics exceed the bounds at 5 percent level of significance.

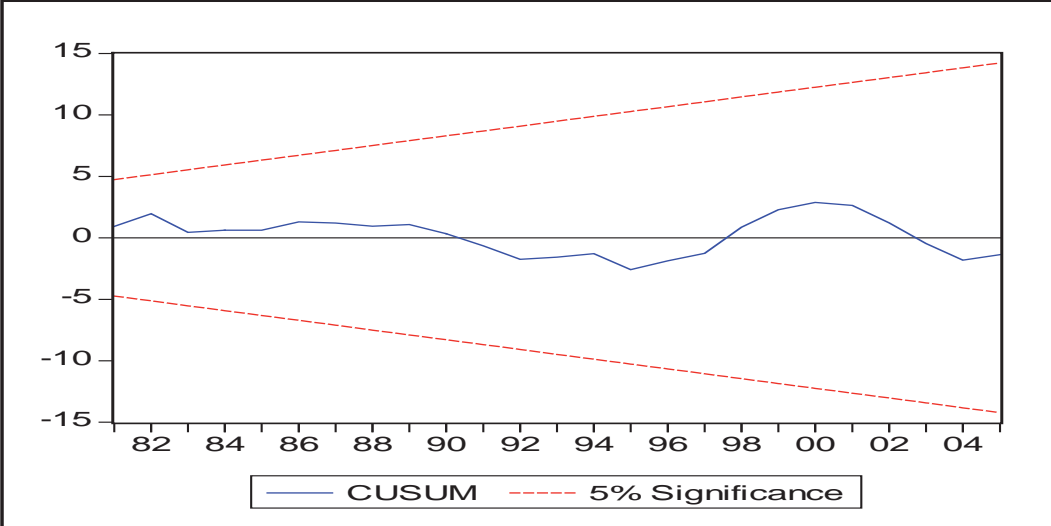

Note. The straight lines represent critical bounds at $5 \%$ significance level.

Figure 2. Plot of cumulative sum of recursive residuals.

64 IJMS $17(2), 47-72(2010)$ 


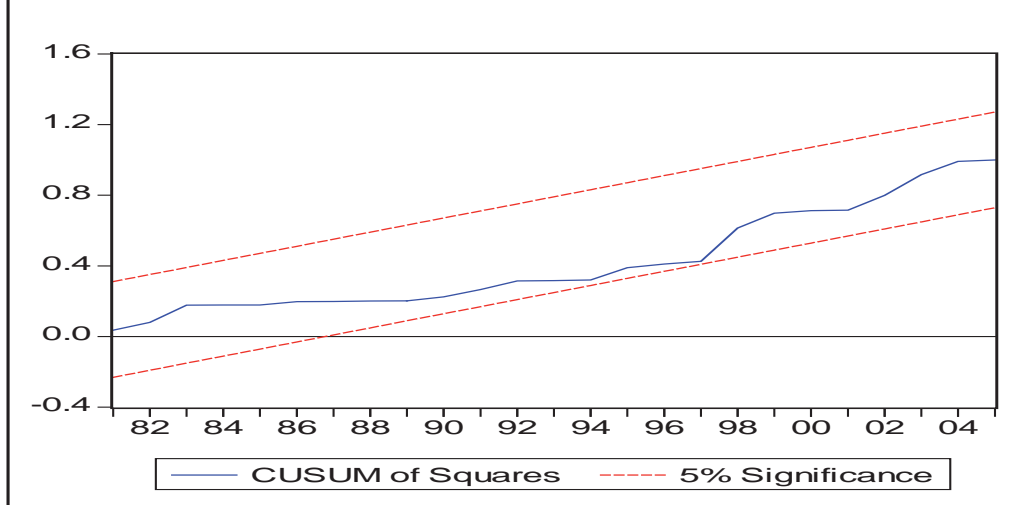

Note. The straight lines represent critical bounds at $5 \%$ significance level.

Figure 3. Plot of cumulative sum of squares of recursive residuals.

Table 7 reports the results of Error Correction Model that is formulation of Equation 1. It is documented by Engle and Granger (1987) that cointegrated variables must have in ECM representation. The $\mathrm{ecm}_{\mathrm{t}-1}$ strategy provides an answer to the problem of spurious correlation in the short-run dynamic relationship between inflation and income inequality. The long run dynamics appear in the set of regressors. Technically, $\mathrm{ecm}_{\mathrm{t}-1}$ (Error Correction Term) seems to measure the speed of adjustment back to cointegrated relationships. Furthermore, $\mathrm{ecm}_{\mathrm{t}-1}$ is posited to be a force affecting the integrated variables to return to their long-run relationship when they deviate from it and thus the longer the deviation, greater would be the force tending to correct the deviation (Banerjee, Dolado \& Mestre, 1998).

Short-run behavior of the determinants of income distribution describes that there is insignificant inverse effect of inflation on income inequality. Real per capita growth worsens income distribution in the short run. Impact of government spending is insignificant with positive sign. Enhancement in investment activities, growth in manufacturing sector and improvement in financial sector's performance reduces income inequality insignificantly. Like long-run enhancement in remittances deteriorates the income distribution in the short run, and similar is the result for human capital formation. Trade appears to prove the Leontief Paradox in Pakistan in both periods.

The signs of the short-run dynamic impacts are maintained in the long run. The equilibrium correction coefficients $\left(\mathrm{ecm}_{\mathrm{t}-1}\right)$ estimated value 
of -0.316 , which is significant at 5 percent level, has the correct sign and imply a fairly high speed of adjustment to equilibrium level after a shock. Approximately $31.6 \%$ of dis-equilibrium from the previous year's shock converges back to the long run equilibrium in the current year. The short-run diagnostic test results are very satisfactory with an absence of 2nd order serial correlation, prevalence of no heteroscedisticity and error term is normally distributed along-with no auto-regressive conditional heteroscedisticity. Ramsey's Reset test for functional form confirms that there is no specification problem in the short-run model.

Table 7

ECM version of FMOLS $(1,1,1,1,1,1,1,2,1,2)$

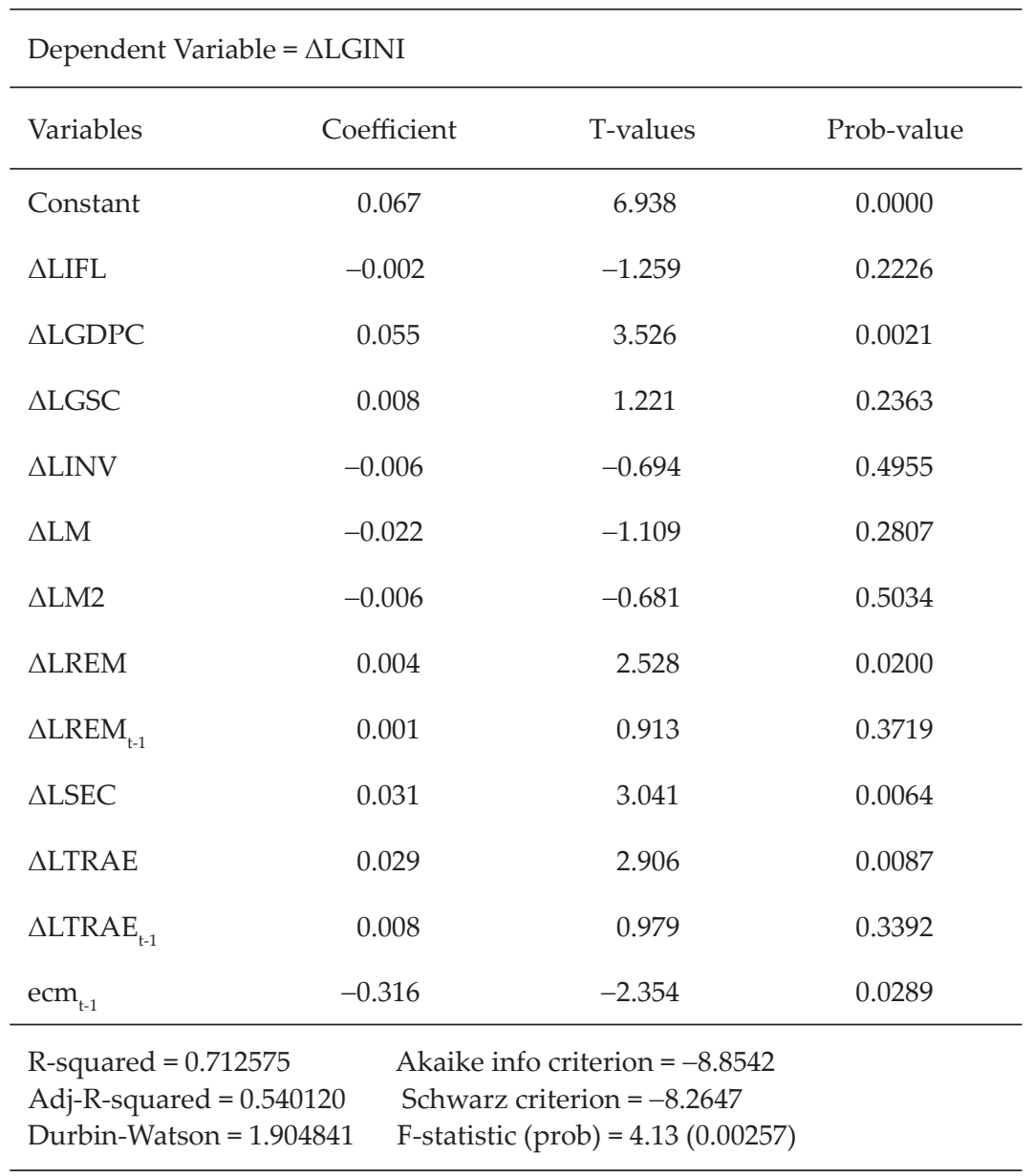




\section{Conclusions and Policy Implications}

The study shows that inflation is progressive in the case of Pakistan but with low magnitude. There also prevails insignificant U-shaped relationship between inflation and income inequality in non-linear or non-monotonic fashion. Per capita income deteriorates income distribution and seems to provide gains to non-poor individuals in the economy. Improvements in manufacturing and investment activities decline income inequality significantly in the long run. Financial development or financial depth seems to redistribute the income distribution insignificantly. International remittances and human capital also appear to increase income inequality in both periods but government spending or size of government worsens income distribution only in a long span of time. Trade and income inequality move in the same direction and Leontief paradox exists in Pakistan not only in the short run but also in the long run. Inverted U-shaped (non-linear factor) curve exists between friendship of trade and income inequality but not significant.

Reduction in the size of government and trade-openness may provide gains to the national economy by diverting resources to developmental projects and collecting import duties through improving the efficiency and reducing corruption in tax administration. An increase in government resources can benefit the poor segments of the society, if resources are allocated to support pro-poor projects or for social development. Therefore, the government should also reduce its size for the sake of pro-poor policies. There is need to have macroeconomic stability to create the right conditions for investment and savings in a small developing economy like Pakistan. Outward oriented policies should be formulated to promote efficiency through improved trade and investment. Strong public institutions and rule of law must be in place to promote good governance and efficient implementation of economic policies. This will not develop the country but also enables the economy to make distribution of income more equal through propoor growth policy.

\section{Endnotes}

1. Regressive (Progressive) means inflation pushes upward (downward) income inequality.

2. Economic Survey of Pakistan (2001-02, p. 108) and see Khan, Hyder and Ahmed (2007) for more details about the recent inflation in Pakistan. 
3. Galli and Hoeven (2001) and Bittencourt (2006).

4. According to Kuznets hypothesis, economic growth is initially accompanied by rise in inequality but as soon as per capita income reaches a certain threshold level, inequality starts to decrease again.

5. See Mocan (1999), Cole and Towe (1996), Powers (1995) and Yoshino (1993).

6. This association, although not economically large, holds for democracies as well as non-democracies (Desai et al. 2005).

7. The degree of income inequality also depends on the sensitivity of investment and consumption to higher rates and lower expected demand, and on the elasticity of employment to output fluctuations (Galli \& Hoeven, 2001).

8. Inflation is progressive through the debtor and creditor channel, with the poor being the debt holders and therefore the main beneficiaries of high rates of inflation (Bittencourt, 2006).

9. For model specification see Zou et al. (2003, 2006).

10. Shahbaz $(2007,2008)$.

11. See Philips and Hansen (1990) for details.

12. The distribution of test statistic is sensitive to the order of lag used. If the lag order used is less than true lag, then the regression estimates will be biased and residual term will be serially correlated. If the order of lag used exceeds the true order, the power of the test is to be reduced.

13. M2 or liquid liabilities is more reliable and comprehensive proxy for financial development or depth. Currency in circulation shows the monetization in the economy. So, liquid liabilities is more pertinent actor for financial development.

14. Government consumption expenditures for the purchase of goods and services (including compensation of employees). It also includes most expenditure on national defense and security, but excludes government military expenditures that are part of government capital formation.

68 IJMS 17 (2), 47-72 (2010) 
15. F-value shows that we reject null hypothesis, indicating structural change in economy started in 1990s, especially reforms in financial sector and other sectors of Pakistan which also given the name of SAP (Structural Adjustment Programme approving by IMF to be implement in Pakistan).

16. Actually, maximum eigen values are difference of trace test values.

17. All the variables are in $\log$ form therefore co-efficient of explanatory variable are called elasticities.

18. We have also checked the impact of political instability through including the dummy, which showed inequality increasing impact.

19. Leontief Paradox asserts that benefit from openness is more likely to favor the relatively privileged groups with in an economy.

20. For comprehensive study see Shahabz $(2007,2008)$ and Agènor, (2003).

\section{References}

Agènor, P.-R. (2003). Does globalisation hurt the poor? World Bank, Mimeo, Washington.

Albanesi, S. (2007). Inflation and inequality. Journal of monetary Economics, 54, 1088-1114.

Bahmani-Oskooee, M., \& Nasir, A. (2004). ARDL approach to test the poductivity bias hypothesis. Review of Development Economics, $8,483-488$.

Bannerjee, A., Dolado, J., \& Mestre, R. (1998). Error-correction mechanism tests for cointegration in single equation framework. Journal of Time Series Analysis, 19, 267-83.

Beetsma, R., \& Ploeg, F. V. D. (1996). Does inequality cause inflation? The political economy of inflation taxation and government debt. Public Choice, 87, 143-162.

Bhattacharya, B., \& Haslag. (2003). Inflationary finance in simple voting model. Iowa State University Department of Economics Working Paper 03012.

Bittencourt, M. F. M, (2006). Macroeconomic performance and inequality: Brazil 1983-94. CMPO Working Paper Series No. 05/114.

IJMS 17 (2), 47-72 (2010) 
Blank, R., \& Blinder, A. (1986). Macroeconomics, income distribution, and poverty. In S. Danziger, \& D. Weinger (Eds.), Fighting poverty: What works and what doesn't. Cambridge, MA: Harvard University Press.

Bulir, A. (2001). The impact of macroeconomic policies on the distribution of income. Annals of Public and Cooperative Economics, 72, 253-270.

Bulir, A., \& Gulde. (1995). Inflation and income distribution: Further evidence on empirical links. IMF working paper 95/86, Washington, International Monetary Fund.

Bum., \& Jeon. (2005). Demographic changes and economic growth in Korea. SKKU ERI WP-06/05.

Bowers, W. Pierce, G. (1975). The illusion of deterrence in isaac ehrlich's work on the deterrent effect of capital punishment. Yale Law Journal, 85, 187-208.

Chu, K., Davoodi, H., \& Gupta, S. (2000). Income distribution and tax and government social spending policies in developing countries. IMF working paper 00/62, Washington, International Monetary Fund.

Cole, J., \& Towe, C. (1996). Income distribution and macroeconomic performance in the United States. IMF working paper 96/97, Washington, International Monetary Fund.

Crowe, C. (2005). Voting for inflation: The political economy of inflation and inequality. OCGD Economy Analysis 5.

Deininger, K., \& Squire, L. (1996). A new data set measuring income inequality. World Bank Economic Review, 10, 565-591.

Desai, R., Olofsgard, A., \& Yousef, T. (2005). Democracy, inequality, and inflation. American Political Science Review, 97, 391-406.

Dollar, D., \& Kraay, A. (2000). Growth is good for the poor. Working paper, Washington, World Bank.

Dolmas, J., Huffman, G., \& Wynne, M. (2000). Inequality, inflation, and central bank independence. Canadian Journal of Economics, 33, 271-87.

Easterly, W., \& Fischer, S. (2001). Inflation and the poor. Journal of Money, Credit, and Banking, 33, 160-178.

Economic Survey of Pakistan. $(2005,2007)$. published by Ministry of Finance, Pakistan.

Ehrlich, I. (1977). The deterrent effect of capital punishment reply. American Economic Review, 452-58.

Engle, R. F., \& Granger, G. W. J. (1987). Co-integration and error correction: Representation, estimation and testing. Econometrica, $55,251-276$.

70 IJMS 17 (2), 47-72 (2010) 
Ferreira, F., Prennushi, G., \& Ravallion, M. (1999). Protecting the poor from macroeconomic shocks: An agenda for action in a crisis and beyond. World Bank Policy Research working paper 2160, Washington, World Bank.

Galli, R., \& Hoeven, R. (2001). Is inflation bad for income inequality: The importance of the initial rate of inflation? EMPLOYMENT PAPER, 2001/29.

Haroon, J. (2006). Does inequality matter for poverty reduction? Evidence from Pakistan's poverty trends. The Pakistan Development Review, 45(3), 439-459.

Johansen, S. (1995). Likelihood-based inference in co-integrated vector autoregressive models. Oxford: Oxford University Press.

Johansen, S. (1991). Estimation and hypothesis testing of co-integrating vectors in Gaussian vector autoregressive models. Econometrica, 59, 1551-1580.

Johansen, S., \& Juselius, K. (1990). Maximum likelihood estimation and inference on co-integration with applications to the demand for money. Oxford Bulletin of Economics and Statistics, $52,169-210$.

Khan, A. A., Hyder, K. H. B., \& Ahmed, Q. M. (2007). Determinants of recent inflation in Pakistan. SPDC's Research Report No. 66.

Layson, S. (1983). Homicide and deterrence. Another view of the Canadian time series evidence. Canadian Journal of Economic, 16, 52-73.

Milanovic, B. (1994). Determinants of cross-country income inequality: An augmented Kuznets' hypothesis. World Bank Policy Research working paper 1246, Washington, World Bank.

MacKinnon, J. G. (1996). Numerical distribution functions for unit root and cointegration tests. Journal of Applied Econometrics, 11, 601-618.

Mocan, N. H. (1999). Structural unemployment, cyclical unemployment, and income inequality. Review of Economics and Statistics, 81,122-134.

Pedroni, P. (1995). Panel co-integration: Asymptotic and unite sample properties of pooled time series test with an application to the PPP hypothesis. Indiana University Working Papers in Economics, No. 95-013.

Pedroni, P. (2000). Fully modified OLS for heterogeneous cointegrated panels. In B., Baltagi, (Ed.), Non-stationary panels, panel co-integration, and dynamic panels, advances in econometrics (pp. 93-130). Vol. 15, Amsterdam: JAI Press.

Pesaran, M. H., \& Pesaran, B. (1997). Working with Microfit 4.0: Interactive Econometric Analysis. Oxford: Oxford University Press. 
Pesaran, Shin., \& Smith. (2001). Bounds testing approaches to the analysis of level relationships. Journal of Applied Econometrics, $16,289-326$.

Phillips, P. C. B., \& Hansen, B. E. (1990). Statistical inference in instrumental variable regression with I (1) Processes. Review of Economics Studies, 57, 99-125.

Phillips, P. C. B., \& Moon, H. R. (1999). Linear regression limits theory for non-stationary panel data. Econometrica, 67, 1057-1111.

Powers, E. T. (1995). Inflation, unemployment, and poverty revisited. Economic Review, Federal Reserve Bank of Cleveland, 3rd quarter, 2-13.

Romer, C. D., \& Romer, D. H. (1998). Monetary policy and the wellbeing of the poor. NBER working paper 6793, Cambridge, MA, National Bureau of Economic Research.

Shahabz, M. (2007). Does globalisation benefit the poor? Evidence from Pakistan. Proceedings of International Conference on Poverty and Distribution Amidst Diversity: Options and Challenges for Development, 2007, pp: 175-200.

Shahabz, M. (2008). Does globalization benefit the poor? Evidence from Pakistan. Journal of Economic and Social Policy, 15, 61-80.

Shahbaz, M., Butt, M. S., \& Aamir, N. (2007). Trade and inequality nexus in Pakistan: Under investigation of alternative techniques. European Journal of Economics, Finance and Administrative Sciences, 9, 57-72.

Stark, O. Taylor, J. E., \& Yitzhaki, S. (1986). Remittances and inequality. Economic Journal, 96, 722-740.

Tanzi, V. (1998). Fundamental determinants of inequality and the role of government. IMF working paper 98/178, Washington, International Monetary Fund.

Yoshino, O. (1993). Size distribution of workers' household income and macroeconomic activities in Japan: 1963-88. Review of Income and Wealth, 39, 387-402. 